УДК 378.016:373.5.011.3-051

DOI: https://doi.org/10.35387/od.1(19).2021.130-140

тринус Олена Володимирівна

- кандидат педагогічних наук, старший дослідник, учений секретар Iнституту педагогічної освіти і освіти дорослих імені Івана Зязюна НАПН України
Trynus Olena-Candidate of Pedagogical Sciences, Senior Researcher, Scientific Secretary of the Ivan Ziaziun Institute of Pedagogical and Adult Education of the NAES of Ukraine

ORCID iD: https://orcid.org/0000-0003-2945-0796

E-mail: evtrinus@gmail.com

\title{
ПРОГРАМА ПРОФЕСІЙНОГО САМОВИХОВАННЯ СУЧАСНОГО ВЧИТЕЛЯ: МЕТОДОЛОГІЧН ТА ПРАКТИЧНІ АСПЕКТИ
}

Анотація. В оглядовій статmі досліджено проблему планування самовиховної діяльності та створення програми профессійного самовиховання. Обгрунтовано методологічні підходи, що забезпечують ефрективність такої діяльності, провідними з яких $\epsilon$ антропологічний, акмеологіний, андрагогічний, системний, діяльнісний, компетентнісний. З'ясовано, що сутність цих підходів до планування самовиховної діяльності полягає в тому, що цей процес визначається фрормуючим у становленні особистості вчителя, $є$ основою досягнення найвищих показників у професійній діяльності, має відбуватися за умови врахування особливостей учителя як дорослої людини до безперервного цілеспрямованого саморозвитку.

Досліджено, що завдання вчителя щодо підвищення рівня професійної компетентності, у контексті компетентнісного підходу, полягають у реалізації власного профресійного потенціалу, оволодінні інноваційними способами й прийомами діяльності, подоланні профресійних та особистісних труднощів та охарактеризовано основні профресійні компетентності сучасного вчителя (предметна, комунікативна, психологічна, організаторська, інфрормаційно-цифрова, рефрлексивна, самоосвітня). Встановлено, що набір цих професійних компетентностей може стати орієнтувальною основою для визначення напрямів самовиховної діяльності, створення індивідуальної програми (плану) професійного самовиховання з урахуванням особливостей і рівнів власного розвитку вчителя. 3 метою удосконалення психологічної компетентності вчителя запропоновано орієнтовний індивідуальний план самоформування вчителем психологічної стійкості у фаховій діяльності.

Зроблено висновок, що програма професійного самовиховання вчителя $є$ основою якісної оцінки його профресійної компетентності, оволодіння навичками аналізу сильних та слабких сторін діяльності, вчасній корекції способів ії виконання з метою більш повної педагогічної самореалізації. 
Ключові слова: профресійне самовиховання; програма профресійного самовиховання; професійна компетентність; сучасний вчитель.

Trynus Olena

\section{PROFESSIONAL SELF-EDUCATION PROGRAM OF A MODERN TEACHER: METHODOLOGICAL AND PRACTICAL ASPECTS}

Abstract. This review paper examines the problem of planning of the self-educational activities and creating of the professional self-educational program. The methodological approaches that ensure the effectiveness of such activities were substantiated. The main of methodological approaches are anthropological, acmeological, andragogical, systemic, activity-based, and competence-based. We explained that the essence of these approaches in the planning of the self-educational activities consist in the fact that this process is determined to be the configurative in the formation of the teacher's personality, is the basis for achieving the highest indicators in professional activity, must be provided when the characteristics of the teacher as an adult to continuous purposeful self-development are considered.

It was investigated that in the context of the competence approach the tasks of the teachers in improving the level of their professional competence are to realize their own professional potential; to master innovative methods and techniques of activity; to overcome professional and personal difficulties. In the paper there were characterized the teacher' basic professional competencies, such as: subjective, communicative, psychological, organizational, informationdigital, reflexive, self-educational.

It was discovered that the set of these professional competencies can become the indicative basis for determining the directions of self-educational activity, creating an individual program (plan) of professional self-education considering the features and levels of the teacher's development. To improve the psychological competence of the teacher, the approximate individual plan for the teacher's self-formation of psychological stability in professional activities was proposed.

The conclusion was made that the program of professional selfeducation of the teacher is the basis for the qualitative assessment of their professional competence, mastering the skills of analyzing the strengths and the weaknesses of the activities, timely correction of the methods of its implementation for the purpose of more complete pedagogical self-realization.

Key words: professional self-education; the program of the professional self-education; professional competence; modern teacher.

Постановка проблеми, їі актуальність. Сучасні соціальноекономічні перетворення зумовлюють визначення нових пріоритетів i перспектив розвитку національної школи та висувають високі вимоги до педагогічної діяльності вчителя, рівня його професійної компетентності. Український учитель має бути творчою, ініціативною особистістю, здатною 
до ефективної організації освітнього процесу, оволодіння новітніми психолого-педагогічними та інформаційними технологіями, готовою до постійного самовдосконалення. Розвиток цих якостей значною мірою залежить від здатності вчителя до фахового зростання, планування цієї діяльності, побудови індивідуальної програми професійного самовиховання.

Аналіз останніх досліджень і публікацій. Теоретичні й практичні аспекти проблеми самовиховання були предметом досліджень провідних фахівців у галузі педагогіки та психології. Концептуальним основам теорії самовиховання присвячені праці Б. Ананьєва, А. Арета, І. Беха, Б. БімБада, В. Краєвського, П. Блонського, Л. Божович, М. Боришевського, Л. Виготського, С. Єлканова, І. Зязюна, О. Кочетова, О. Леонтьєва, Ю. Орлова, С. Рубінштейна, Л. Рувинського та ін. Методичні аспекти організації самовиховання стали предметом аналізу Н. Болдирева, В. Бондаревського, Я. Колдунова, О. Кучерявого, В. Оржеховської, Г. Селевка, В. Сухомлинського та ін. Технологічні аспекти організації самовиховання особистості розглядаються у роботах Л.Гашпар, С. Даньшевої, А. Калініченко, І. Краснощок, І. Середи, А. Тубельського та ін. Незважаючи на значну кількість праць, у яких вивчається різні аспекти проблема самовиховання, залишається недостатньо розкритим питання самопрограмування вчителем цього процесу, створення прогнозу щодо можливостей власного самовдосконалення шляхом створення програми професійного самовиховання.

Мета статті полягає у дослідженні проблеми планування самовиховної діяльності та створення програми професійного самовиховання.

Виклад основного матеріалу. У вітчизняній педагогічній і психологічній думці самовиховання трактується як: формування людиною своєї особистості відповідно до свідомо поставленої мети, вища форма виявлення саморуху особистості, що розвивається, де вона виступає суб'єктом свого розвитку (Зязюн, 2008); систематична й свідома діяльність людини, спрямована на вироблення в собі бажаних якостей, позитивних рис волі й характеру, усунення негативних звичок (Гончаренко, 2011); засіб професійного становлення й розвитку, якісного руху до найвищих рівнів педагогічної майстерності (Кучерявий, 2015); свідома, доцільна відповідній меті, діяльність особистості, що сприяє самовдосконаленню та самореалізації (Хатунцева, 2018) тощо.

3 огляду на вищесказане, професійне самовиховання вчителя визначаємо як цілеспрямовану, систематичну діяльність, спрямовану на усвідомлену позитивну самозміну, вироблення здатності керувати своїми психічними станами, розвивати професійно важливі якості, пристосовувати природні задатки, нахили, здібності до норм фахової діяльності (Сотська \& Тринус, 2020).

Професійне самовиховання розглядаємо як структуроване явище, компонентами якого є: вибір особистісно значущих цілей і завдань; визначення змісту самовиховної діяльності; обрання засобів впливу на 
себе; отримання результатів самовиховання.

Ефективність професійного самовиховання забезпечується врахуванням найважливіших змістових компонентів педагогічної діяльності та $€$ підгрунтям її планування, створення програми самовиховання. Програму професійного самовиховання вчителя визначаємо як програму дій щодо досягнення конкретних цілей самовиховання з урахуванням вимог педагогічної професії.

На наше переконання, планування самовиховної діяльності сприятиме обґрунтування сукупності методологічних підходів, провідними 3 яких $€$ антропологічний, акмеологічний, андрагогічний, системний, діяльнісний, компетентнісний.

Сутність антропологічного підходу при розгляді планування самовиховної діяльності вчителя полягає в тому, що цей процес визначається формуючим у становленні особистості вчителя, передбачає постійне усвідомлення значущості вивчення самого себе, своїх здібностей, можливостей з метою свідомої зміни особистісних і професійно значущих якостей, посилення мотивації пізнавальної активності щодо опанування педагогічною професією, $€$ передумовою набуття найвищого рівня профресійної майстерності.

Акмеологічний підхід у контексті нашого наукового пошуку відкриває можливості розгляду створення програми роботи над собою як основи досягнення вчителем найвищих показників у професійній діяльності. 3 позицій зазначеного підходу становлення і саморозвиток учителя розглядається як досягнення ним професійного «акме», підвищення рівня самосвідомості, самопізнання, оволодіння прийомами самоосвіти та самовиховання. Акмеологічний підхід дозволяє проектувати етапи професійного самовиховання вчителя 3 метою досягнення ним найвищого рівню професіоналізму (Дубасенюк, 2015).

Андрагогічний підхід передбачає врахування особливостей вчителя, як дорослої людини, до безперервного цілеспрямованого саморозвитку у педагогічній діяльності шляхом самовиховання та планування такої діяльності. Успішність її здійснення обумовлена врахуванням відповідних андрагогічних принципів: принципу усвідомленості самопрограмування особистості; принципу цілеспрямованості, ціннісної орієнтації самовиховання; принципу незалежності та суб'єктності самовиховання; принцип опертя на життєвий досвід; принцип єдності самовиховання та професійної діяльності.

У контексті нашого долідження це передбачає наявність постійної потреби до самозміни, вироблення власних поглядів щодо сутності самовиховання, усвідомлення і самоформування основних цілей, цінностей, норм діяльності, професійних ідеалів, проектування та реалізацію програми самовиховання з метою вироблення індивідуального стилю педагогічної діяльності, свідоме перетворення власних професійних характеристик.

Планування самовиховної діяльності вчителя з позицій системного підходу розглядається як багаторівнева, динамічна система, що має 
особливу внутрішню організацію, специфічні функціональні характеристики і має за мету досягнення вчителем вершин свого саморозвитку, еталону професійних, соціальних та індивідуальних досягнень. Системні уявлення щодо самовиховання вчителя уможливлюють вивчення таких відносно самостійних компонентів, як особистість учителя та процес його самовиховання не ізольовано, а в їхньому взаємозв'язку. Системоутворюючим фактором самовиховання $€$ суб'єктивний принцип формування особистості вчителя, який дає змогу розглядати його з позиції активного суб'єкта усвідомленого та цілеспрямованого розвитку, передбачає самостійність й активність у виборі цільового орієнтиру.

Діяльнісний підхід до з'ясування сутності планування самовиховної діяльності вчителя базується на уявленні про діяльність як невід'ємного складника структури особистості, фрактора її розвитку та саморозвитку, шляху до професійного становлення. У процесі самовиховної діяльності вчитель виступає як активний суб'єкт пізнання, в якого цілеспрямовано формуються вміння та навички до самовиховання, його планування, виконання, регулювання та оцінки результатів власної діяльності. Саме через діяльність і в процесі діяльності відбувається самоактуалізація особистості вчителя, його професійне самовдосконалення.

Програма самовиховних дій учителя проєктується з усвідомленням цілей, провідними з яких є: розвиток мотивації роботи над собою; свідоме цілепокладання і планування самовиховних дій; розвиток культури самовиховання; керування цією діяльністю.

Компетентнісний підхід розглядається як один 3 важливих концептуальних принципів, що визначає сучасну методологію самовиховання вчителя. У сучасній науковій літературі поняття «компетентність» трактується по різному: як сукупність знань і умінь, необхідних для ефективної професійної діяльності (Гончаренко, 2011); як високий рівень умілості, спосіб самореалізації особистості, форма вияву їі здібностей (Зязюн, 2005); як здатність фахівця від початку професійної діяльності на рівні визначеного державою певного стандарту відповідати суспільним вимогам професії шляхом ефективної професійної діяльності (Іванова, 2008).

Компетентнісний підхід до планування самовиховної діяльності спрямовує вчителя до розвитку спеціальних педагогічних здібностей та умінь, необхідних для успішного оволодіння професією та досягнення високих результатів у фаховій діяльності. Завдання вчителя щодо підвищення рівня професійної компетентності, у цьому контексті, полягають у реалізації власного професійного потенціалу, оволодінні інноваційними способами й прийомами діяльності, подоланні професійних та особистісних труднощів.

На нашу думку, до основних професійних компетентностей учителя як основи створення програми професійного самовиховання, необхідно віднести предметну, комунікативну, психологічну, організаторську, інфрормаційно-цифрову, рефлексивну, самоосвітню компетентності (табл. 1). - 
Основні професійні компетентності сучасного вчителя

\begin{tabular}{|c|c|}
\hline $\begin{array}{l}\text { Компе- } \\
\text { тентність }\end{array}$ & $\begin{array}{c}\text { Педагогічні вміння, які вчитель має розвинути в собі } \\
------------- \\
\text { Педагогічні здібності, які вчитель має сформувати }\end{array}$ \\
\hline $\begin{array}{c}\text { Предмет- } \\
\text { на компе- } \\
\text { тент- } \\
\text { ність }\end{array}$ & $\begin{array}{l}\text { Педагогічні вміння: } \\
\text { - вміти визначати предметний зміст та послідовність його } \\
\text { викладання з урахуванням результатів навчання, визначених } \\
\text { Державними стандартами освіти та типовими освітніми } \\
\text { програмами; } \\
\text { - вміти застосовувати міжпредметні зв'язки та інтеграцію } \\
\text { змісту різних освітніх галузей під час підготовки та проведення } \\
\text { навчальних занять; } \\
\text { - вміти добирати доцільні фрорми, методи та засоби } \\
\text { навчання відповідно до визначених мети і завдань уроку та } \\
\text { індивідуальних особливостей учнів; } \\
\text { - вміти застосовувати інноваційні технології навчання. } \\
\text { Педагогічні здібності: } \\
\text { - глибоко оволодівати навчальним матеріалом; } \\
\text { - швидко і творчо оволодівати методами навчання учнів; } \\
\text { - доступно, зрозуміло передавати учням навчальний } \\
\text { матеріал, викликати інтерес до предмету; } \\
\text { - здійснювати д дослідницьку роботу, } \\
\text { ознайомлюватися з новими досягненнями у відповідній галузі } \\
\text { знань. }\end{array}$ \\
\hline $\begin{array}{c}\text { Комуніка- } \\
\text { тивна } \\
\text { компе- } \\
\text { тент- } \\
\text { ність }\end{array}$ & $\begin{array}{l}\text { Педагогічні вміння: } \\
-\quad \text { вміти будувати ефективні комунікативні дії в певному колі } \\
\text { ситуацій міжособистісної взаємодії з метою досягнення } \\
\text { гуманістично спрямованої мети виховання учнів; } \\
-\quad \text { вміти добирати мовні і мовленнєві засоби залежно від } \\
\text { потреб, завдань взаємодії вчителя з учнями; } \\
-\quad \text { вміти розвивати психофізичні властивості власної } \\
\text { особистості } \quad \text { м метою оволодіння вміннями професійно- } \\
\text { педагогічного мовлення. } \\
\text { Педагогічні здібності: } \\
\text { в спілкуватися з учнями, знаходити підхід до них, } \\
\text { встановлювати з ними педагогічно доцільні стосунки; } \\
-\quad \text { чітко висловлювати думки і почуття з допомогою мови й } \\
\text { невербальних засобів (міміки, жестів, пантоміміки); } \\
-\quad \text { володіти чіткою дикцією, багатим словниковим запасом, } \\
\text { уникати мовленнєвих помилок; } \\
-\quad \text { володіти педагогічним тактом. }\end{array}$ \\
\hline
\end{tabular}




\begin{tabular}{|c|c|}
\hline $\begin{array}{c}\text { Психоло- } \\
\text { гічна } \\
\text { компе- } \\
\text { тент- } \\
\text { ність }\end{array}$ & $\begin{array}{l}\text { Педагогічні вміння: } \\
\text { - вміти використовувати психологічні знання в роботі з } \\
\text { учнями; } \\
\text { - вміти володіти собою, контролювати власний фрізичний } \\
\text { стан, фрормувати психологічну стійкість; } \\
\text { - вміти використовувати власний психофрізичний апарат як } \\
\text { інструмент виховного впливу. } \\
\text { Педагогічні здібності: } \\
\text { - розуміти особистість учня і його психічні стани } \\
\text { (психологічна спостережливість); } \\
-\quad \text { розвивати здатність до емпатії; } \\
\text { - емоційна стабільність, здатність не допускати зривів } \\
\text { діяльності при значних психічнихі фізичних навантаженнях. }\end{array}$ \\
\hline $\begin{array}{c}\text { Організа- } \\
\text { торська } \\
\text { компе- } \\
\text { тентн- } \\
\text { ість }\end{array}$ & $\begin{array}{l}\text { Педагогічні вміння: } \\
\text { - вміти планувати та управляти навчально-виховним } \\
\text { процесом; } \\
\text { - опанувати низку нових сучасних ролей учителя (коуч, } \\
\text { ментор, тьютор, новатор, модератор, фасилітатор); } \\
\text { - вміти здійснювати педагогічну діагностику; } \\
\text { - вміти планувати та реалізовувати індивідуальну освітню } \\
\text { траєкторію розвитку дитини для його становлення як } \\
\text { особистості, громадянина, інноватора. } \\
\text { Педагогічні здібності: } \\
\text { - створювати умови для навчання; } \\
\text { - моделювати та проводити уроки; } \\
\text { - організовувати самостійну діяльність учнів; } \\
\text { - керувати пізнавальною активністю учнів; } \\
\text { - налагоджувати едективну взаємодію } \text { учасників } \\
\text { навчально-виховного процесу на засадах педагогіки } \\
\text { партнерства. }\end{array}$ \\
\hline $\begin{array}{c}\text { Інфоорма- } \\
\text { ційно- } \\
\text { цифррова } \\
\text { компе- } \\
\text { тент- } \\
\text { ність }\end{array}$ & $\begin{array}{l}\text { Педагогічні вміння: } \\
-\quad \text { вміти орієнтуватися в інформаційному просторі; } \\
\text { - вміти здійснювати пошук і критично оцінювати } \\
\text { інформацію, оперувати нею у фаховій діяльності; } \\
\text { - вміти організовувати навчально-виховний процес з } \\
\text { використанням технологій дистанційного навчання, створювати } \\
\text { електронне портфоліо, брати участь в он-лайн науково- } \\
\text { практичних масових заходах тощо; } \\
\text { - вміти виконувати санітарні та гігієнічні правила під час } \\
\text { використання комп'ютера на уроці. } \\
\text { Педагогічні здібності: } \\
\text { - здатність до вирішення завдань професійної діяльності } \\
\text { за допомогою компютерної техніки; } \\
\text { - володіти прийомами компютерного мислення; } \\
\text { - здатність до саморозвитку у сфрері інфрормаційних } \\
\text { технологій. }\end{array}$ \\
\hline
\end{tabular}




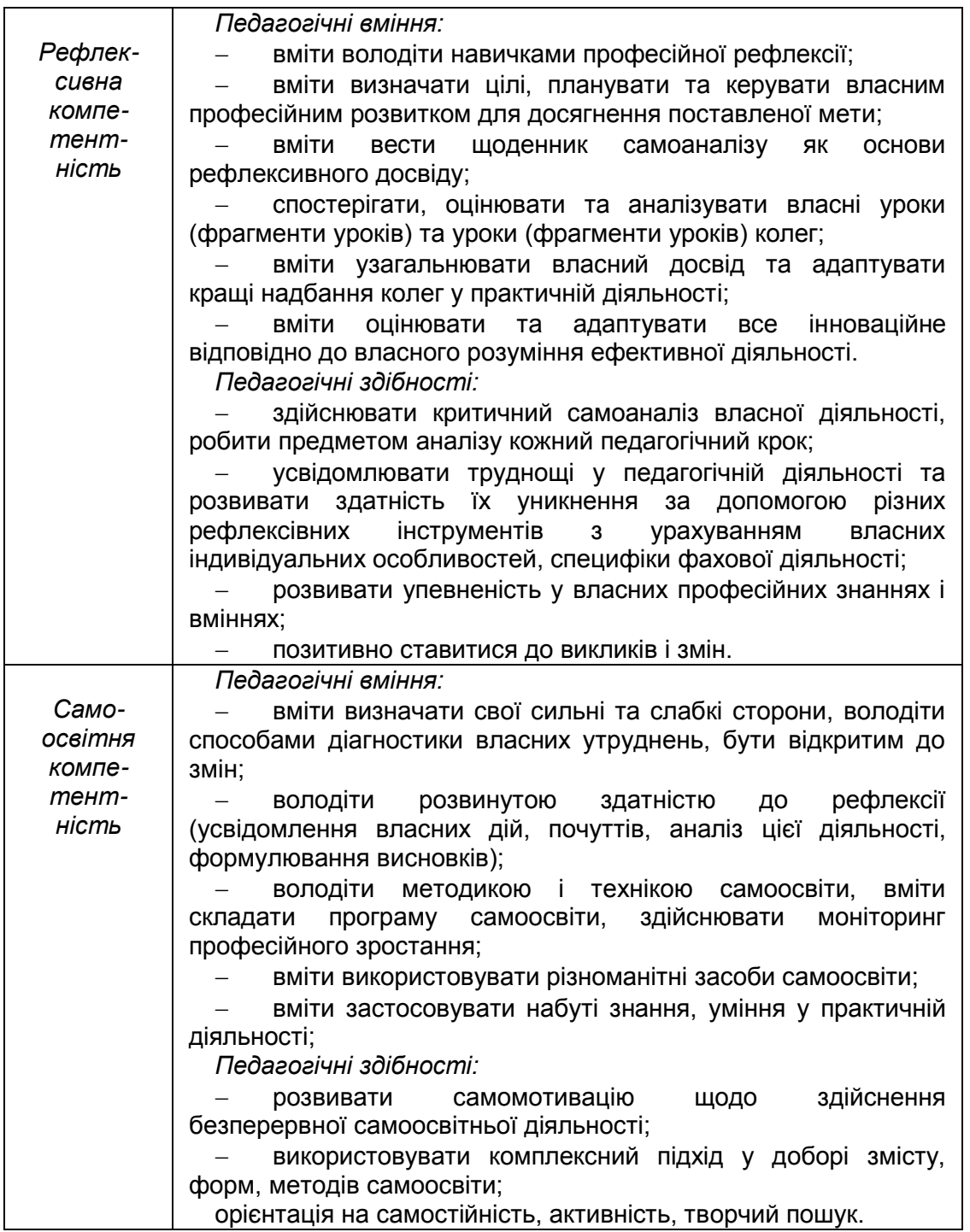

Набір професійних компетентностей може стати орієнтовною основою для визначення напрямів самовиховної діяльності вчителя, створення індивідуальної програми (плану) професійного самовиховання 3 урахуванням особливостей і рівнів саморозвитку.

Наприклад, з метою удосконалення психологічної компетентності 
вчителя пропонуємо орієнтовний індивідуальний план самоформування вчителем психологічної стійкості у фаховій діяльності, структура якого містить такі компоненти: визначення цілей самовиховання; самотестування своїх професійно значущих якостей; окреслення розвитку якостей, що недостатньо сформовані; визначення шляхів усунення негативних якостей; вибір засобів самовиховання; самоконтроль та самооцінка самовиховання; корекція плану самовиховання (табл. 2).

Таблиця 2

Орієнтовний індивідуальний план самоформування вчителем психологічної стійкості у фаховій діяльності

\begin{tabular}{|c|c|c|c|}
\hline . & $\begin{array}{c}\text { Шляхи } \\
\text { досягнення }\end{array}$ & Засоби досягнення & $\begin{array}{c}\text { Термі- } \\
\text { ни } \\
\text { вико- } \\
\text { нання }\end{array}$ \\
\hline 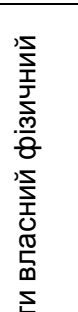 & $\begin{array}{l}\text { 1. Здійснювати } \\
\text { діагностування } \\
\text { рівня емоційної } \\
\text { стабільності д } \\
\text { здатності } \\
\text { керування } \\
\text { власним } \\
\text { психологічним } \\
\text { самопочуттям. }\end{array}$ & 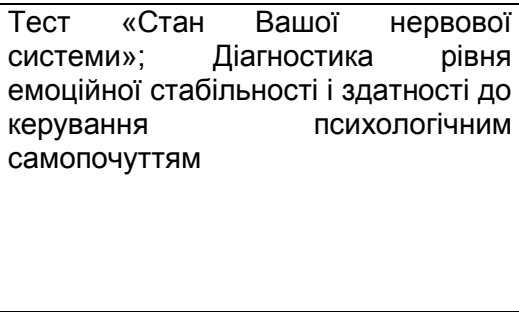 & Постійно \\
\hline 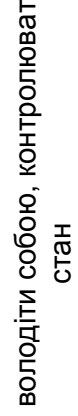 & $\begin{array}{l}\text { 2. Визначати } \\
\text { педагогічні } \\
\text { здібності й уміння, } \\
\text { що недостатньо } \\
\text { розвинуті. }\end{array}$ & 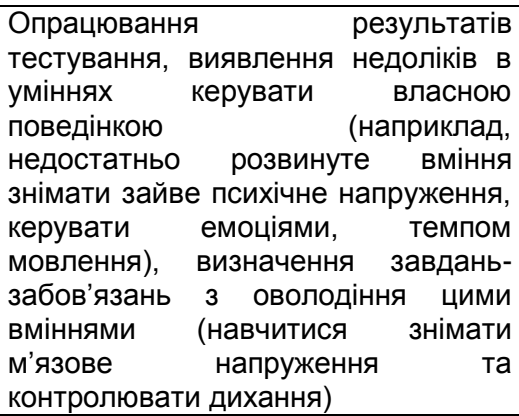 & Постійно \\
\hline 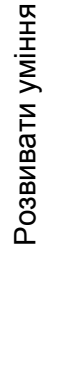 & $\begin{array}{l}\text { 3. Визначати } \\
\text { шляхи розвитку } \\
\text { вміння знімати } \\
\text { м'язове } \\
\text { напруження та } \\
\text { контролювати } \\
\text { дихання. }\end{array}$ & 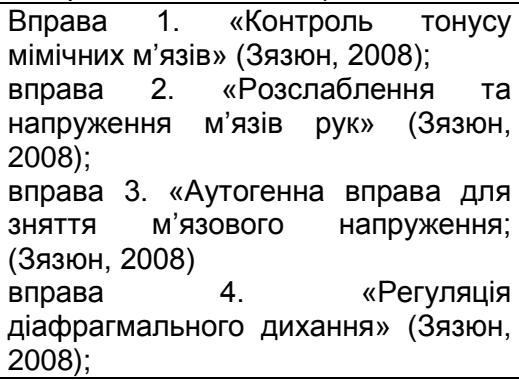 & Постійно \\
\hline
\end{tabular}




\begin{tabular}{|c|c|c|}
\hline & $\begin{array}{lcc}\text { вправа } & 5 . & \text { «Налагодження } \\
\text { ритмічного дихання» (Зязюн, 2008). }\end{array}$ & \\
\hline $\begin{array}{l}\text { 4. Здійснювати } \\
\text { самоконтроль та } \\
\text { самооцінку } \\
\text { результатів } \\
\text { самовиховної } \\
\text { діяльності. }\end{array}$ & $\begin{array}{lr}\text { Методика фріксації } & \text { результатів } \\
\text { самовиховної } & \text { діяльності } \\
\text { використанням } & \text { календаря } \\
\text { (Кучерявий, 2010); } & \\
\text { Методика використання } & \text { засобів } \\
\text { самовиховання } & \text { «Хатинка» } \\
\text { (Кучерявий, 2010). } & \\
\end{array}$ & Постійно \\
\hline $\begin{array}{l}\text { 5. Здійснювати } \\
\text { корекцію плану } \\
\text { самовиховання. }\end{array}$ & $\begin{array}{l}\text { Корекція самовиховної діяльності на } \\
\text { основі контролю, аналізу проміжних } \\
\text { результатів і потреб у подальшому } \\
\text { профресійному саморозвитку }\end{array}$ & Постійно \\
\hline
\end{tabular}

Висновки і перспективи подальших досліджень. Таким чином, планування самовиховної діяльності відіграє провідну роль у процесі самозмінювання вчителя з метою вдосконалення його особистостісних і профресійних характеристик. Програма самовиховання вчителя $є$ основою якісної оцінки його професійної компетентності, оволодіння навичками аналізу сильних та слабких сторін діяльності, вчасній корекції способів її виконання з метою більш повної педагогічної самореалізації.

Подальщими напрямами досліджень проблеми планування самовиховної діяльності $€$ вивчення методів самопізнання вчителя, складання авторських програм самовиховання тощо.

\section{Список використаних джерел}

Гончаренко, С.У. (2011). Український педагогічний енциклопедичний словник. Рівне: Волинські обереги.

Дубасенюк, О.А. (2015) Акмеологічний підхід як стратегічний орієнтир особистісно-орієнтованої педагогічної освіти. Проблеми освіти, 84. 25-30.

Зязюн, І.А. (2008). Педагогічна майстерність: підручник. Київ: СПД Богданова А. М.

Зязюн, І.А. (2005). Філософія поступу і прогнозу освітньої системи. Педагогічна майстерність: проблеми, пошуки, перспективи: монографія. Київ. 10-18.

Іванова, С.В. (2008). Функціональний підхід до визначення професійної компетентності вчителя біології та організація її вдосконалення в закладі післядипломної освіти. Вісник Житомирського державного університету імені І. Франка, 42. 106-110.

Кучерявий, О.Г. (2015). Акмеологічні детермінанти самоосвіти і самовиховання майбутніх учителів як засоби формування педагогічної майстерності. Естетика і етика педагогічної дії, 12. 9-19.

Кучерявий, О.Г. (2010). Професійне самовиховання у вищій школі: підручник. Київ: Освіта України. 
Сотська, Г.І., Тринус, О.В. (2020). Андрагогічні аспекти профресійного самовиховання сучасного вчителя. Імідж сучасного педагога, 4, 59.

Хатунцева, С.М. (2018). Теоретичні і методичні засади формування у майбутніх учителів готовності до самовдосконалення у процесі індивідуалізації профресійної підготовки: дис. ... д-ра пед. наук. Бердянськ.

\section{References (translated and transliterated)}

Honcharenko, S.U. (2011). Ukrainskyi pedahohichnyi entsyklopedychnyi slovnyk [Ukrainian pedagogical encyclopedic dictionary]. Rivne: Volynski oberehy [in Ukrainian].

Dubaseniuk, O.A. (2015) Akmeolohichnyi pidkhid yak stratehichnyi oriientyr osobystisno-oriientovanoi pedahohichnoi osvity [Acmeological approach as a strategic landmark of personality-oriented pedagogical education]. Problemy osvity - Problems of education, 84. 25-30 [in Ukrainian].

Ziaziun, I.A. (2008). Pedahohichna maisternist [Pedagogical skills]: pidruchnyk. Kyiv: SPD Bohdanova A. M. [in Ukrainian].

Ziaziun, I.A. (2005). Filosofiia postupu i prohnozu osvitnoi systemy [Philosophy of progress and forecast of the educational system]. Pedahohichna maisternist: problemy, poshuky, perspektyvy - Pedagogical skills: problems, searches, prospects: monohrafiia. Kyiv. 10-18 [in Ukrainian].

Ivanova, S.V. (2008). Funktsionalnyi pidkhid do vyznachennia profesiinoi kompetentnosti vchytelia biolohii ta orhanizatsiia yii vdoskonalennia $v$ zakladi pisliadyplomnoi osvity [Functional approach to determining the professional competence of a biology teacher and the organization of its improvement in the institution of postgraduate education]. Visnyk Zhytomyrskoho derzhavnoho universytetu imeni I. Franka - Zhytomyr Ivan Franko State University Journal, 42. 106-110 [in Ukrainian].

Kucheriavyi, O.H. (2015). Akmeolohichni determinanty samoosvity i samovykhovannia maibutnikh uchyteliv yak zasoby formuvannia pedahohichnoi maisternosti [Acmeological determinants of self-education and self-education of future teachers as a means of forming pedagogical skills]. Estetyka $i$ etyka pedahohichnoi dii - Aesthetics and ethics of pedagogical action, 12. 9-19 [in Ukrainian].

Kucheriavyi, O.H. (2010). Profesiine samovykhovannia u vyshchii shkoli [Professional self-education in high school]: pidruchnyk. Kyiv: Osvita Ukrainy [in Ukrainian].

Sotska, H. I., Trynus, O. V. (2020). Andrahohichni aspekty profesiinoho samovykhovannia suchasnoho vchytelia [Andragogical aspects of professional self-education of a modern teacher]. Imidzh suchasnoho pedahoha - The image of a modern teacher, 4, 5-9 [in Ukrainian].

Khatuntseva, S.M. (2018). Teoretychni i metodychni zasady formuvannia u maibutnikh uchyteliv hotovnosti do samovdoskonalennia u protsesi indyvidualizatsii profesiinoi pidhotovky [Theoretical and methodological principles of formation of future teachers' readiness for self-improvement in the process of individualization of professional training]: dys. ... dokt. ped. nauk. Berdiansk [in Ukrainian]. 